想的亡考えられる。

試験管法で緒方法は抗原稀釈洼で抗体検出を行つてい るが，我々も之に準じた方法をプレート法で試反た。こ の際, 補体は 2.5 単位と 4.0 単位の 2 種類の濃度のもの を使用し，検出率を高めることが心要であつた。

我々は, 実験や検查の過程において極めて小量の検 体，即ち血清や抗原を用いで補体結合反応を行は福ばな らない場合に往々遇偶する。この際にはプレート法は大 いに役立ち是非試むべき方法であると信ずる。ルーチン ワークに括いても，梅毒血清診断に上記の方法を行えば 武験管洗條の手数を大巾に減ずることが可能である。

\section{むすび}

Fulton, Dumbell により考案されたプラスチック板上 の微量補体結合反応を梅毒血清カルヂオライピン反応系 に試みた。溶血系の検討では $0.4 \%$ の緬羊血球を $8 \sim 16$ 単位の溶血素で感作することが判定上適しているととが 認められた。

抗原, 抗体, 補体を変化させた 3 次限定量で抗原過剩 域に反応の場の縮小が認められた。

試験管法 (緒方法) に準じプレート板上で抗原稀釈に よる補体結合反応を試みた処，2 種類の濃度の補体を使 用すれば，試験管法に劣らない成績が得られた。ルーチ ンワークにも今後試みるべき方法であると考えられる。

終りに本研究実施に際し多くの援助をらけた検查室の 稲福盛栄, 高田俊三郎両君飞深謝します。

(本論交の要旨は第 30 回日本細菌学会総会に扣いて発
表した）

\section{文献}

1) Fulton, F. and Dumbell, K. R. : J. Gen. Microbiol. 3, 97, 1949.

2) Kraft, L. M. and Melnick, J. L. : J. Exp. Med. 92, 483, 1950.

3) Le Bouvier, G. L. : Brit J. Exper. Path. 34 : 300, 1953.

4) Black, F. L. and Melnick, J. L. : Yale J. Biol and Med. $26: 385,1954$.

5）北岡正見：第 14 回日本医学会総会特別講演集, $313,1955$.

6) Mayer, M. M., Osler, A. G., Bier, O. G. and Heidelberger, M. : J. Exp. Med. 84 : 535, 1946.

7）緒方富雄 : 梅毒の新しい血清学的検查法, 南山 堂, 第 1 版, 1951 .

8）厚生省編箱：衞生検查指針 II. $128,1950$.

9) Casals, Olitzki, P. K. and Anslow, R. O.: J. Exp. Med. $94: 123,1951$.

10) Nelson, R. A. Jr. and Mayer, M. M. : J. Exp. Med. $89: 369,1949$.

11) Surino, V. R. and De Lamater, E. D.: Am. J. Syph, $36: 353,1952$.

12) Hardy, P. H. Jr. and Nell E. E. : J. Exp. Med. $101: 367,1955$.

13) Portnoy. J. and Magnuson, H. J. : J. Immunol $75: 348,1955$.

14) Mayer M. M., Eaton B. B. and Heidelberger, M. : J. Immunol, $53: 31,1946$.

15）進藤宙二：Virus $2: 149,1952$.

13 巻 6 号 室橋 ・関論交

\title{
正誤 表
}
p. 844 上より 3 行目
正
誤
$0.2 \sim 0.3 \quad 0.02 \sim 0.03$

13 巻 10 号 束村 $\cdot$ 中村論文

\begin{tabular}{|c|c|c|}
\hline & 正 & 誤 \\
\hline p. 916 & $\sum_{j=1}^{j}$ & $\sum_{j=1}^{i}$ \\
\hline $\begin{array}{l}\text { p. } 917 \\
\text { 左段, 式(7) }\end{array}$ & $\mathrm{S}_{\mathrm{dil}}=\sqrt{\frac{\mathrm{j} \sum_{\mathrm{i}=1}^{\mathrm{i}}\left(\overline{\mathrm{x}}-\overline{\mathrm{x}}_{\mathrm{i}}\right)^{2}}{\mathrm{i}(\mathrm{j}-1)}}$ & $S_{d i 1}=\sqrt{\frac{j \sum_{i=1}^{i}\left(\bar{x}-i\left(\bar{x}_{i}\right)^{2}\right.}{i(j-1)}}$ \\
\hline $\begin{array}{l}\text { p. 917, 右段の最 } \\
\text { 初の式 }\end{array}$ & $\left(\overline{\mathbf{x}} \pm \sqrt{(\mathrm{A})^{2}+(\mathrm{B})^{2}}\right) \times 10^{\mathrm{m}}$ & $\left(\overline{\mathrm{x}} \pm \sqrt{(\mathrm{A})^{2}+(\mathrm{B})^{2}} \times 10^{\mathrm{m}}\right.$ \\
\hline $\begin{array}{l}\text { p. } 918 \text {, 灰段, 本 } \\
\text { 交, 9行目 }\end{array}$ & 理 論 值 & 理 想, 值 \\
\hline
\end{tabular}

